NBER WORKING PAPER SERIES

PENSIONS AND FIRM PERFORMANCE

Steven G. Allen

Robert L. Clark

Working Paper No. 2266

NATIONAL BUREAU OF ECONOMIC RESEARCH 1050 Massachusetts Avenue

Cambridge, MA 02138

May 1987

Final draft of chapter for the 1987 Research Volume of the Industrial Relations Research Association titled Human Resources and Firm Performance, edited by Morris Kleiner, Richard Block, Myron Roomkin, and Sidney Salsburg. Stan Leibowitz gave us useful advice on the measurement of profit rates. We have received helpful comments from Richard Ippolito and the University of North Carolina Human Resource Economics Workshop and excellent research assistance from Linda Shumaker and Myra Ragland. The research reported here is part of the NBER's research program in Labor Studies. Any opinions expressed are those of the authors and not those of the National Bureau of Economic Research. 
NBER Working Paper \#2266

May 1987

\title{
Pensions and Firm Performance
}

\begin{abstract}
This paper examines how pension plans affect employee behavior and firm performance. Theoretically, the impact of pensions on firm performance cannot be predicted. Firms with pensions should have lower turnover rates and more efficient retirement decisions; their employees will be less likely to shirk. On the other hand, pension compensation is not very closely linked to worker performance and there is some risk that turnover may fall too much. The evidence indicates that although wages do not seem to fall with pension compensation, profit rates are not affected by pension coverage. This suggests that pension coverage is associated with higher productivity, a proposition that is supported by indirect evidence on pensions, turnover, and productivity but not by direct tests of how pension coverage and productivity are correlated.
\end{abstract}

Steven G. Allen

Department of Economics and Business

Box 8110

North Carolina State University Raleigh, NC 27695-8110
Robert L. Clark Department of Economics and Business Box 8110 North Carolina State University Raleigh, NC 27695-8110 


\section{Introduction}

Pension benefits represent a form of deferred compensation that a worker receives after he retires from a firm, provided he has met certain age and service requirements. The magnitude of these benefits depends on the nature of the employment contract and whether the worker and the firm have fulfilled the obligations of that contract. This chapter examines the role of pensions as a form of compensation and how pensions are used as a component of personnel policy. Such a review requires a clear understanding of how future pension benefits are evaluated by workers and financed by firms. Having determined these concepts, we can assess the influence of pensions on firm performance. Pensions are strictly regulated by the federal government and so our examination will include a brief review of current regulations and how they temper the impact of pensions on firm performance.

Our examination of pensions begins with a brief overview of the growth and development of the employer pension system in the United States. This includes a discussion of the distribution of pensions by worker and firm characteristics. In section II, specific plan characteristics are described and their importance is discussed. Next, we present several alternative rationales for why workers and unions want pensions as part of their compensation. Section IV presents competing models of the pension contract and develops predictions for the effect of pensions on compensation and performance. The impact of pensions on employee behavior is considered from a theoretical perspective in section V; section VI assesses the evidence concerning the impact of pensions on firm performance. The final section 
reports our conclusions and discusses some areas where further research would be useful.

Growth and Development of Employer Pensions

While public pensions in the United States are as old as the republic (dating to benefits for Revolutionary War veterans), private pensions first appeared in the late nineteenth century. Greenough and King (1976) credit the American Express Company with establishing the first formal employer pension in 1875. Early pensions were generally found in railroads, banking, and public utilities. Prior to World War II, growth in pension coverage was slow; however, in the immediate post-war period there was a rapid increase in the number of employers offering pensions and the number of workers covered by a pension. The proportion of wage and salary workers in the private sector covered by an employer pension grew from 25 percent in 1950 to over 50 percent in 1984. Most of this growth occurred prior to 1975. In the last decade, coverage rates have changed only modestly. The proportion of covered workers actually fell from 56 to 52 percent between 1979 and 1983 (Andrews, 1985). Growth in coverage and increases in benefits raised the percentage of payroll going to pensions from 1 percent in 1950 to 6 percent in 1980 (Fields and Mitche11, 1984).

Ippolito (1986a) estimates that in 1984 there were 788,000 pension plans, of which 744,000 covered fewer than 100 participants. Allowing for duplicate coverage, these plans contained 57.5 million active participants and 8 million annuitants. Public employees have always been more likely to be covered by an employer pension than private sector workers. Currently, over 90 percent of state and local workers and all federal workers are covered by an employer pension (Munne11, 1979). 
How can the observed pattern of development of pensions be explained? Several factors may have stimulated the surge in pension coverage after World War II. A comprehensive assessment of the economic rationale for the existence of pensions is provided in subsequent sections of this chapter. However, it is useful to point to several changes that occurred during the 1940 s which may have provided the impetus to increased pension coverage. First, the 1942 amendments to the Internal Revenue Code clarified and expanded tax treatment of pensions and precluded the establishment of pension funds limited to corporate officers (Greenough and King, 1976). Second, wartime stabilization policy made it easier to increase fringe benefits than cash wages. Third, in 1949 the National Labor Relations Board ruled in the Inland Steel decision that pensions were a proper subject for collective bargaining. This action removed a constraint that limited unions' ability to achieve pension coverage for their members and may have altered union attitudes toward seeking pension benefits (Allen, Melone, and Rosenbloom, 1984).

Are there similar specific events that might explain the slowdown in the growth of the coverage rate in the last decade? In 1974, the Employee Retirement Income Security Act (ERISA) was enacted. This legislation imposed a sweeping new set of regulations on the use and funding of pensions. In the last decade, a number of additional modifications to the pension laws have been instituted. These regulations have raised the administrative costs of pensions and reduced the range of permitted pension contracts. Some have speculated that restrictions on the use of pensions may partially explain the slowing in the growth of pensions. However, Ippolito (1986b) concludes that ERISA had only a small effect on plan terminations. 
In addition to the new regulations, the growth in pension coverage may have slowed simply because workers who were most likely to desire pensions were already covered. Relatively high current coverage rates among high wage workers, unionized workers, and employees in large firms imply that further extension of pension coverage may proceed more slowly in the future.

\section{Patterns of Pension Coverage}

The odds that any individual will be covered by a pension plan on his job vary tremendously with both personal and job characteristics. The most up-todate information is reported in the pension supplement to the May 1983 Current Population Survey (CPS). We restrict the sample to full-time private wage and salary workers. Those who have jobs which are covered by collective bargaining agreements are much more likely to be included in a pension plan than nonunion workers. The coverage rate for private sector workers is 82 percent for union versus only 44 percent for nonunion workers, as shown in Table 1 . Union contract coverage is correlated with a number of other personal and job characteristics which in turn are also highly correlated with pension coverage (e.g., wages, industry). In order to estimate the net effect of union contract coverage, we estimated a probit equation for pension coverage which included all of the variables in Table 1 . The probit results showed that, other things equal, those covered by union contracts have a 26.3 percentage point higher probability of being covered by a pension than nonunion workers.

The size of the workplace (establishment) and the size of the company, especially the latter, are also important correlates of pension coverage. In establishments with fewer than 25 workers, only 28 percent of the work force is covered by a pension plan. Coverage rates jump to 51 percent in establishments 
with 25 to 99 workers and reach 86 percent in establishments with 1,000 or more workers. The share of workers covered by a pension in companies with fewer than 25 workers is a paltry 17 percent. This percentage also rises with size, reaching 80 percent in firms with 1,000 or more employees.

These two size measures are obviously correlated, so it is reasonable to ask which matters the most. According to the probit analysis, the resounding answer is company size. Other things equal (including company size), there is only a 10 percentage point difference between pension coverage probability in the smallest and largest establishment size categories. In contrast, there is a 15 percentage point difference between companies with fewer than 25 employees and those with 25 to 99 employees. This widens to a 45 percentage point difference between companies with fewer than 25 employees and those with 1,000 or more.

The pattern of pension coverage across different age groups suggests that workers gradually sort themselves into jobs with pensions over time. Only about a quarter of workers between 16 and 24 are covered by pensions. Pension coverage rises to 50 percent for those between 25 and 34 ; it is slightly above 60 percent for all older workers. Other things equal, the odds of being covered are 13 percentage points higher for 25 to 34 year olds and 20 to 24 percentage points higher for 35 to 64 year olds than for 16 to 24 year olds. Although patterns within a cohort over time may be quite different from the across cohort patterns, they suggest the possibility that if a worker is not covered by a pension by the time he reaches the 35 to 44 age group, given the low turnover rates among older workers, there is a good chance he never will be covered. 
Because of the favorable tax treatment of pensions, it should come as no surprise that pension coverage is also strongly correlated with average hourly earnings. The coverage rate for workers earning less than $\$ 4$ an hour is a mere 13 percent in contrast to coverage rates above 70 percent for those earning $\$ 10$ an hour or more. Most of this difference cannot be explained by other factors, as indicated by the probit results.

Workers with jobs in mining, manufacturing, and transportation and utilities have higher pension coverage rates than those in other industries. However, much of the difference in coverage rates across industries can be explained in terms of other factors such as firm size, earnings, and collective bargaining coverage. For instance, the probit results show that workers in wholesale trade have a 12 percentage point greater probability of being covered by a pension than service industry workers, holding all other factors constant. The difference between workers in durable manufacturing and services turns out to be even smaller ( 9 percentage points), despite the fact that the raw, unadjusted coverage rate for durable manufacturing ( 72 percent) is much higher than that for wholesale trade (52 percent).

Table 1 also indicates that pension coverage rates are lower for persons in service occupations (compared to blue or white collar occupations), lower for those living in the West, higher for men, higher for married workers, and higher for high school and college graduates. The magnitude of these differences is relatively small in relation to the differences in pension coverage associated with union contract coverage, company size, age, average hourly earnings, and industry. 


\section{Significance of Pension Benefits and Funds}

The growth of pensions over the past four decades has increased their importance in a number of areas. First, pensions have grown as a source of income to older Americans. Ippolito (1986a) estimates that the mean initial pension annuity for 1984 beneficiaries was $\$ 6,360$ representing 23 percent of their final earnings. A U.S. Department of Labor Study (1985) reports that the replacement rate rises with the level of final earnings. Replacement rates for 1978 retirees rose from 14 percent for those with earnings less than $\$ 6,000$ to 20 percent for those with earnings between $\$ 10,000$ and $\$ 11,999$ to 25 percent for retirees with $\$ 14,000$ to $\$ 19,999$ in final earnings. A total of $\$ 70$ billion was paid to retirees in pension benefits in 1984 . Over the past quarter century, pension benefits have come to represent an increasing proportion of retiree income.

Second, pension funds represent a growing proportion of invested funds in the United States. Ippolito (1986a) estimates that 1984 pension assets totaled one trillion dollars. These funds represented 22.8 percent of all corporate equity and 49.9 percent of all corporate bonds. The dramatic rise in pension funds is shown by comparing these values to their 1950 rates. In 1950, pensions held less than 1 percent of corporate equity and only 13.1 percent of all corporate bonds. Another measure of the size of pension assets is that in 1981 pension assets per worker were equal to $\$ 10,907$ which represented 75 percent of annual earnings.

II. Pension Plan Characteristics

Pension plans are of two basic types: defined contribution and defined benefit. Within a particular plan type, pensions differ in their plan 
formulas, vesting requirements, maximum benefit provisions, social security integration, age of normal and early retirement, reductions for early retirement, and benefit increases associated with delayed retirement. This section examines these diverse characteristics among pensions and indicates how these differences affect behavior at the workplace.

Types of Pension Plans

Defined contribution and defined benefit plans are the two basic types of pension plans. Defined contribution plans are by far the most common type of plan representing 71 percent of all plans in 1984. However, these plans tend to be provided by relatively small employers. As a result, less than 20 percent of all pension participants are covered by defined contribution plans. Table 2 shows the greater incidence of coverage by defined contribution plans among small employers. Sixty-three percent of pension participants in nonunion plans covering less than 100 participants are in defined contribution plans. This compares to a defined contribution coverage rate of only 12.9 percent for small union plans and 0.7 percent for large union plans. The greater use of defined contribution plans among small employers is attributable to lower administrative costs, plus the tremendous costs of compliance with government regulations of defined benefit plans for small firms (Smeeding 1983; Mitchell and Andrews 1981).

In a defined contribution plan, the firm promises to contribute each period a fixed amount of money to an individual's pension account. In some plans workers will also be allowed or even required to make contributions. The funds are invested by the plan and accumulate throughout the worker's life. The benefit at retirement is determined by the size of the individual's pension fund at that time. The worker bears all of the risk concerning the rate of 
return on the invested funds. However, the worker does not risk losing pension benefits if he leaves the firm prior to retirement or if the company goes out of business, terminates the pension, or fires the worker. Property rights are clearly defined; the funds in defined contribution plans belong to the worker. These plans have no impact on turnover, except for the simple fact that workers covered by such plans have more total compensation than other workers if all other variables (including cash earnings) are held constant. They also have no effect on retirement decisions, except to the extent that workers face liquidity constraints and are unable to use their benefits as collateral (in which case they may have to postpone retirement). The key factor to recognize is that there are no bonuses or penalties associated with the choice of retirement age in defined contribution plans.

Defined benefit plans are much more common among large employers and as a result, almost 80 percent of pension participants are covered by defined benefit plans. These plans are more complex than defined contribution plans and federal regulations tend to be more restrictive. In a defined benefit plan, the worker is promised a benefit upon retirement based on plan generosity, years of service, and in some cases earnings. The firm must set aside sufficient dollars to provide for these future benefits. The rate of firm contributions is regulated by the government. As we will explain in detail below, a worker who leaves prior to the retirement age will lose benefits relative to the worker who remains with the firm. Thus in these plans, the worker bears risks associated with plan termination, his own desire to quit, and potential firing by the firm. However, the firm bears all risks concerning the rate of return on the pension fund. The use of these plans to influence turnover and retirement is explored in sections IV and V. 
P1an Characteristics

Several plan characteristics play a critical role in determining benefit levels, along with any loss of benefits associated with leaving the job. Much of this discussion is relevant only to defined benefit plans. The primary plan characteristics are reviewed below along with a discussion of economic effects and the frequency of their use.

Benefit Formula. Defined benefit plans typically use one of three formula types. The most frequently used formula type is the terminal earnings formula which determines benefits by multiplying years of service by an average of the final three or five years earnings and a generosity parameter. In the 1983 Employee Benefit Survey of Medium and Large Firms (EBS), plans using these formulas cover 54 percent of all participants. The career earnings formula is similar, except that the salary average is based on all earnings with the firm instead of just the final three or five final years. These plan formulas cover 14 percent of participants. Dollar amount formulas provide a fixed dollar amount to all retirees or multiply years of service times a fixed dollar amount. These formula types cover 28 percent of participants.

Earnings based formulas are used more frequently by plans covering professional workers and in noncollectively bargained plans. Obviously, these plans allow for a variance in pension benefits that reflects earnings. Dollar amount formulas are used more frequently in plans covering production workers and unionized workers. These formulas tend to reduce the variance of the benefit distribution relative to the earnings distribution and to flatten the age-compensation profile of union workers relative to nonunion workers (Allen and Clark, 1986). 
Vesting. Vesting pertains to the portion of a worker's specified benefit to which he is legally entitled upon leaving the firm. Prior to 1987 , regulations allowed firms to select one of three vesting rules. These were 100 percent vesting of accrued benefits after 10 years of service, 25 percent vesting of accrued benefits after 5 years of service with additional vesting accruing each year until the worker is 100 percent vested after 15 years, and 50 percent vesting of accrued benefits when age and service add up to 45 with 100 percent vesting 5 years later. Almost all companies adopted the 10 year, 100 percent vesting rule (Schulz, 1985). Tax legislation in 1986 altered vesting standards to be either 100 percent vested after 5 years or graded vesting with a worker being 50 percent vested after 3 years and accruing additional vesting each year until he is 100 percent vested after 7 years.

If a worker leaves prior to being vested, he will receive no retirement benefits. Even if the worker achieves 100 percent vesting, there is still a penalty for leaving the firm, which we will describe in detail below.

Post-retirement Increases. If pension benefits are not increased after retirement, their real value will decline in the presence of inflation. Until recently, it was widely believed that pension benefits were fixed in nominal terms. Surveys of large firms indicate that less than 5 percent of private plans automatically increase benefits in response to inflation. The lack of automatic adjustments does not necessarily imply that no post-retirement increases are granted. Approximately two-thirds of large plans provided one or more ad hoc increases during the last half of the 1970s (King, 1982). Allen, Clark, and Sumner (1986) report that between 1973 and 1979 average benefits for persons already receiving benefits in 1973 increased by 24 percent during a period when the Consumer Price Index rose by 63 percent. 
Table 3 shows that benefit increases were larger and more prevalent in collectively bargained plans. The method of benefit increase also varied by collective bargaining status (Allen and Clark, 1986) with bargained plans being more likely to use methods that provide the largest percentage increases to those with the lowest benefits.

Maximum Benefit Provisions. Some pensions incorporate specific plan rules in order to set a maximum pension benefit. Some type of maximum benefit provision is incorporated into pension plans covering 42 percent of participants represented in the 1983 EBS. The most prevalent form of limitation to benefits is to limit credited service to a specific number of years. This type of limitation is used in plans covering 31 percent of participants. This limit is usually 30 years or more. Terminal earnings plans are much more likely to include such limits than plans with other types of benefit formulas. Eleven percent of participants are in plans that limit benefits to either a maximum percent of terminal or career earnings or to a maximum flat dollar amount.

Social Security Integration. Firms are permitted to reduce pension benefits by including the worker's Social Security benefit as part of total pension benefits or costs. Just over half of all participants in the EBS were in plans that integrated pension benefits with Social Security benefits. Smaller plans are more likely to be integrated (President's Commission on Pension Policy, 1980). Until 1987, the Internal Revenue Service regulations allowed two types of integration: the excess method and the offset method. The excess method allows firms to provide greater benefits based on earnings above the Social Security taxable earnings limit than on earnings below this limit. In an excess plan which does not consider years of service, the pension benefit 
based on earnings above the specified limit could not exceed 37.5 percent of the plan benefits based on earnings below that level. Plans could set this compensation limit no higher than the current year's Social Security taxable earnings limit. Most plans set the limit well below the allowable amount and tended not to have adjusted this earnings amount as the Social security earning limit rose (Urban Institute, 1982).

The offset method allows a certain portion of the retiree's primary insurance amount (PIA) to be subtracted from the pension benefit. Prior to 1987, the offset could not exceed 83.33 percent of the worker's PIA. Most surveys indicate that integrated plans did not use the maximum possible offsets. In offset plans, the most frequently used percentage is 50 percent of the PIA. It remains to be seen how plans will adjust to the 1986 tax changes governing Social Security integration.

Retirement Age and Gains From Continued Employment. Pension plans specify an age of normal retirement, which is the time that a worker can retire and receive full pension benefits as provided by the pension formula. In recent years the age of normal retirement has been lowered in many plans. In the EBS sample, only 36 percent of the participants were covered by plans using 65 as the normal retirement age. Another 33 percent were in plans that specified ages between 60 and 64 and 11 percent were in plans with ages between 55 and 59. Approximately 18 percent of plans had no age requirement at all; eligibility in these plans depends solely on length of service.

Virtually all defined benefit plans allow for retirement prior to the normal retirement age at reduced benefits. In most plans, the reduction in benefits is less than the actuarial equivalent of the normal retirement benefit.

Since the 1978 amendments to the Age Discrimination in Employment Act, firms 
have not been able to mandatorily retire workers prior to the age of 70 . Thus, workers may continue to work past the normal retirement age. Firms can erect strong pension incentives for older workers to retire at the normal retirement age. First, relatively few firms provide any actuarial increase in benefits for work past the normal retirement age and as a result pension wealth may fall after this point. Second, in 1985 approximately half of all participants were covered by plans that did not continue to credit years of service and earnings after the date of normal retirement. Thus, the pension is fixed in nominal terms at the normal retirement age. The worker can continue on the job but will lose that year's pension benefits.

Legislation enacted in 1986 has altered both the mandatory retirement and the pension accrual regulations. For most firms, mandatory retirement is now entirely forbidden as a firm personnel policy regardless of the age of the worker. In addition, firms providing a pension cannot discontinue wage and service accruals at a specified age. These changes reduce the ability of firms to provide incentives to older workers to retire.

III. Why Do Workers and Unions Want Pensions?

Pension coverage has expanded through the labor force and the magnitude of pension benefits has increased in response to the actions of various labor market agents striving to maximize their objective functions. To understand the development of the pension system, we must determine who the players are, what their objectives are, and how pensions can help them achieve their objectives. These negotiations are conducted in a changing regulatory environment which alters the incentives associated with the use of a pension. 
The primary agents in bargaining concerning pensions are workers, firms and unions. Workers seek to maximize total compensation for a given amount of labor supply or effort. Firms seek to maximize profits. The objectives of unions tend to be more complex and may include reducing income inequality, providing economic security for workers and retirees, and raising wages and benefits. The remainder of this section examines how pensions help workers and unions achieve their primary objectives. Sections IV and V analyze how pensions affect firm performance.

Worker Utility and the Desire for Pensions

Economic theory assumes that individual workers attempt to maximize utility subject to their personal budget constraint. A simplified version of this maximization process has the worker's utility as a function of total compensation and the amount of labor supplied. For a given amount of labor supplied, the worker seeks to maximize total compensation. Compensation may come in many forms other than current cash such as job safety, comfort on the job, and all types of employee benefits including pensions.

For the purposes of this part of the discussion, assume that the firm is a neutral agent and is willing to sell the worker any type of benefit at a price that is equal to the firm's cost of acquiring this benefit. The worker pays for each benefit by receiving less in cash compensation. Theoretically this compensating differential would allow the worker to buy the desired amount of any benefit offered by the firm. The worker would purchase benefits until the marginal utility of this benefit was equal to marginal value of a dollar of cash spent on other goods and services (Rosen 1974). With no taxes or other governmental interference, benefits would be bought only if the firm can buy 
these goods at a lower cost than the worker could purchase them in the market or if the benefit is tied to the job and can only be bought from the firm.

Neither of these explanations for the existence of fringe benefits seem to apply in the case of pensions. Today, there are financial intermediaries which give individuals access to a wide spectrum of investment opportunities; workers are not required to save through a pension to gain access to financial markets. The diversity of investment opportunities available to individuals also makes it unlikely that the expected rate of return to pension funds is greater than the expected rate of return that an individual investor could receive.

During the early development of the pension system these conditions may not have prevailed. Prior to the development of large mutual funds, small investors may have been unable to obtain widespread diversification. Therefore, capital market regulations and institutions may have played a role in the initial growth of pensions. Even today there may remain differences in transactions costs associated with individual investments versus investment through a pension fund. Despite this potential offset, it seems highly unlikely that the widespread pension coverage in today's economy can be explained in terms of lower transactions costs.

A much more convincing rationale is the tax status of pensions in comparison to current earnings. Firms with qualified plans make tax deductible contributions to a pension fund that is used to provide future benefits to current workers. The value of these contributions is not viewed as current compensation to the worker and therefore is not subject to the individual income tax in the current period. The return to assets in these funds is also not taxable. Instead, benefits are taxed when they are received and the 
expectation is that the worker will be in a lower tax bracket at that time. Prior to the advent of Individual Retirement Accounts, workers had no other form of savings that received such preferential tax treatment.

Pension contributions by firms are also exempt from Social Security and Unemployment Insurance payroll taxes. For the worker the value of pension contributions permanently escapes the employee's share of the Social Security tax, although the resulting lower earnings means that future Social Security benefits will also be lower. Given today's benefit structure, the expected loss in benefits will be less than the savings from reduced taxes and the worker's lifetime income will rise.

As a result of the differential tax treatment, workers could increase total compensation by agreeing with the firm to establish a pension plan. The value of a pension plan is dependent on the prevailing tax rate. Thus, as tax rates rise, more workers would be expected to request their firms to institute a pension. The tax effect is also an important determinant of the distribution of plans across workers in any given year. High wage workers are much more likely to be covered by a plan than low wage workers, as shown in Table 1.

\section{Union Objectives and the Use of Pensions}

Unions have played an important independent role in the expansion of pension coverage and the development of certain pension characteristics. Historically, unions have consistently exerted pressure on both employers and governments to provide economic security for older workers through both private pensions and Social Security. Private pension plans became much more widespread after the Inland Steel decision made pensions a permissible topic for collective bargaining. Even today workers who are covered by collective bargaining 
agreements are much more likely than other workers to receive a pension when they retire.

Despite the difficulties associated with defining union objectives in precise terms, it is quite clear that pensions can help achieve many possible union objectives. First, the preferences of older, more senior workers receive much more weight in determining the terms of the employment contract under unionism. These workers prefer a compensation package with lower wages and higher retirement income, holding the cost of the package constant. As a result of the greater weight given to their preferences, the package becomes more likely to contain a pension along with other provisions which increase the income and economic security of older workers. Second, pensions can be used to compress the distribution of total compensation among union members. Allen and Clark (1986) show how the choice of benefit parameters can reduce pension inequality among workers.

Third, pensions can serve the interests of union officers. Albert Rees (1962) argued that by obtaining a new benefit for their members, union leaders can gain much more credit for innovation than they would if they had obtained a wage increase of equal value. In cases where the union has some control over the pension plan, the scope of authority of the leadership is significantly greater as well. Fourth, unions have an organizational advantage in certain aspects of pension administration. For instance unions often administer plans in industries with small employers or short job durations. Without unions there probably would not be very many workers covered by private pensions in the construction industry. Unions also monitor plan behavior so that employers do not renege on explicit or implicit contracts. Finally, higher wages place 
union members in higher marginal tax brackets, thereby increasing the demand for all forms of tax-free or tax-deferred compensation, including pensions.

\section{What Is The Pension Contract?}

The influence of pension plans on firm performance depends on the nature of the pension contract and how this contract is evaluated by the worker and the firm. Two models of pension contracts have been developed in the economics literature. The first is primarily based on the work of Bulow (1982) who derived the value of pensions under a strict legal or explicit contract. This model assumes that a worker considers only the value of benefits that a firm is legally required to pay if the worker were to leave the firm at the end of the current period. This model clearly applies to defined contribution plans and many contend that it applies to defined benefit plans as well. The second model, developed in recent work by Ippolito (1985a, 1986a) and others, allows for the existence of implicit long term employment contracts and focuses on the role of defined benefit plans in such contracts. This model assumes that a worker views the employment contract as an implicit promise by the firm to retain the worker (subject to performance requirements) until retirement and to pay a benefit based on final pay.

These models yield different predictions concerning incentives for the worker to quit and incentives for the worker to provide a high level of job performance to minimize risks of being fired. In addition, these theories of the pension contract predict alternative patterns of life cycle compensation. In this section, each of these models is examined in detail and the corresponding relationship with firm performance is assessed. The final 
objective of this section is to analyze the role of collective bargaining in models of the pension contract.

\section{The Explicit Contract View of Pensions}

The basic premise of the explicit contract model is that workers act as if the employment contract is for only one period. Of course, if both parties are agreeable employment may be continued on a period by period basis. Since the worker knows that he may be terminated at the end of the current period, he is unwilling to accept any compensation that is contingent on his remaining with the firm for an extended period of time. This type of contract implies that the worker will value future retirement benefits on the basis of work to date and will consider only benefits that the firm is legally required to pay.

Under explicit employment contracts, workers face no loss in future benefits if they quit their current job. As a result, pensions cannot be used to reduce turnover or encourage a higher level of job performance. Despite the lack of a capital loss associated with leaving a job, pensions still represent an important component of compensation and will affect the growth rate of earnings of a worker covered by a pension. In addition, coverage by a pension alters the cash wage offer necessary to entice a worker to leave his present job. To understand these effects, a brief discussion of the evaluation of pension wealth is necessary along with the related concept of annual pension compensation.

The expected present value of future pension benefits, pension wealth, is determined by finding the discounted value of a life annuity beginning at retirement. The magnitude of the annual flow is governed by the pension formula and the individual's own work history. The most frequent form of 
benefit formula is one where the benefit is determined by multiplying the number of years of service by a fixed percentage of the worker's average earnings during the final years of employment. Pension wealth is calculated by using the worker's current years of service and salary average along with the prevailing benefit formula. These values, along with assumptions concerning survival probabilities and the market interest rate, are sufficient to calculate pension wealth for any worker.

Pension compensation is the change in pension wealth resulting from continued employment. From the above discussion, one can see that pension wealth rises due to an additional year of service and to any increase in earnings. Mathematical derivations of pension compensation are found in Bulow (1982), Clark and McDermed (1986a) and Kotlikoff and Wise (1985). These papers illustrate that if earnings are rising with tenure, pension compensation grows more rapidly than earnings.

The explicit contract literature assumes that in each year a worker is paid total compensation equal to the value of his output. With perfect capital markets, the cost to the firm of funding pension benefits is the same as the value that the worker places on these benefits. If there are no other forms of compensation, the wage plus pension compensation will equal the worker's output. With pension compensation growing more rapidly than earnings, pension compensation will increase as a proportion of total compensation as the worker continues on the job. This lifetime pattern of compensation is shown in Table 4.

Under the explicit contract model, pension wealth and pension compensation are zero until the worker is vested in the pension plan. After vesting but still during the early working years, pension compensation is small both in 
absolute terms and as a percentage of total compensation. If the worker remains on the job, pension compensation grows rapidly and may reach 30 to 50 percent of total compensation during the final working years prior to retirement. This increase in pension compensation produces a corresponding growth in pension wealth to which the worker is legally entitled.

Although there is no loss in pension wealth if the worker leaves his job, pensions still affect the wage offer from a competing firm that is necessary to entice the worker to leave his current job. A competing firm that has no pension must offer a cash wage equal to the worker's current earnings plus pension compensation. Even if the competing firm has a pension that is identical to the one on the worker's current job, the wage offer must exceed current earnings. This follows because pension compensation will be lower on the new job, either because the worker will not be vested or because he will have fewer years of service on the new job.

This discussion would seem to indicate that under the explicit contract model pensions would tend to reduce turnover by raising the reservation wage at other firms. This is an incorrect inference. Since the model assumes a spot market with all firms willing to pay total compensation equal to the worker's marginal product, competing firms are willing to pay the higher cash wage solely because they are not providing as much pension compensation.

Several important predictions can be derived from this model. First, there is no pension loss from leaving the job so pensions should not reduce quit rates. For the same reason, pensions cannot be used as a personnel policy to encourage reduced worker malfeasance. Second, workers covered by pensions should have a flatter age-earnings profile than workers who receive their entire compensation in cash. In addition, Bulow (1982) has shown that earnings 
should exhibit discrete jumps at several times associated with large changes in pension compensation. For instance at vesting, pension compensation goes from zero to hundreds of dollars. Assuming no similar increase in the value of the worker's output takes place, wages must adjust in the opposite direction. There should be no ad hoc post-retirement increases in benefits for workers covered by an explicit contract. For the most part, these predictions are contradicted by the available evidence.

\section{The Implicit Contract View of Pensions}

An alternative to the single period contract described above is a long term employment contract which requires future payment for current labor services. Terms of such contracts may be either explicit as in formal contracts or implicit. Recently, a series of papers by Lazear $(1979,1981,1983,1986)$ and Malcolmson (1984) have pointed out how implicit labor contracts can be used to modify worker behavior and improve firm performance. Pensions can be an important component of these contracts. The key factor in the use of pensions in an implicit contract is the difference in the implied value of pension wealth if the worker remains with the firm until retirement and the actual value of the pension if the worker leaves prior to fulfilling the terms of the contract.

Firms and workers may enter into an implicit contract in order to reduce labor turnover and increase the level of worker productivity. These objectives are accomplished by imposing a wealth loss on workers who quit the firm prior to the end of the contract or who are fired due to shirking on the job. The wealth loss is produced by assuming that the worker is paid each period total 
compensation equal to his output; however, the value of the compensation is conditional on the worker continuing to meet the terms of the contract. Pension compensation comprises the conditional component of total compensation. In this model, pension wealth is based on the worker's expectation that he will remain with the firm until he retires. As such, the expected pension benefit is based on his projected final earnings. The difference between the calculation of pension wealth using the implicit contract method and the explicit contract model is the use of projected final earnings instead of current earnings to determine the value of current pension wealth. The use of projected earnings will produce a higher estimate of pension wealth.

In an implicit contract, the worker receives pension compensation based on the change in pension wealth as calculated using projected earnings. In this case, pension wealth increases only because of additional years of service. Pension compensation will be greater than under the explicit contract early in life, but will not rise as rapidly with years of service. Ippolito (1985a) has shown that under certain conditions pension compensation will represent a constant proportion of total compensation throughout work life.

The worker is assumed to pay for a pension conditional on remaining with the firm until retirement. If he leaves the firm, his actual pension will be considerably smaller than the pension he was paying for in the form of reduced earnings. Thus, termination of the employment contract imposes a capital loss on the worker. This capital loss equals the difference between pension wealth based on projected earnings and pension wealth under the legal method. Formulas for calculating the capital loss are reported in Ippolito (1985a) and Allen, Clark, and McDermed (1986). 
The existence of this potential loss will make the worker less likely to quit and more likely to perform at a level that will not tempt the firm to fire him. The value of this capital loss rises during the early work years and then begins to decline as the worker approaches the age of retirement. An example of this effect is shown in Table 5. For many workers, the loss in pension wealth associated with quitting may represent half of annual earnings or with high rates of inflation perhaps as much as a full year's earnings (Ippolito, (1985b, 1987), Allen, Clark and McDermed, (1986)).

The implicit contract model generates several predictions concerning earnings and worker performance. First, workers covered by a pension should be less likely to quit and should be more willing to provide a high level of effort to reduce the probability of being fired. Second, the rate of growth of earnings for workers covered by a pension should be approximately the same as the growth of earnings of similar workers not covered by a pension. Available evidence seems to support the latter prediction (Clark and McDermed, 1986b; Mitchell and Pozzebon 1986: Ippolito, 1985a): evidence on turnover is examined in detail in Section VI.

The Pension Contract under Collective Bargaining

The impact of unionism on any pension contract, whether explicit or implicit, hinges on the decision making process within the union and how various groups exert their influence on the determination of the bargaining agreement. In the simple "monopoly union" framework, there is only one prediction about union impact: pension plans should be more generous in all respects. This means higher initial benefits, larger increases in benefits 
after retirement, earlier eligibility for benefits, and fewer restrictions on participation and vesting.

Public choice models recognize the conflicts within the union concerning the division of monopoly rents. Despite the well known difficulties involved with specifying the political mechanisms at work, two of the most tractable public choice approaches yield the prediction that the pension contract will be tilted in favor of older workers. Freeman (1985) has shown formally that in a median voter approach, the pension contract will be written to match the preferences of inframarginal workers, whereas in a nonunion setting, it will be written to match the preferences of the marginal worker.

The inframarginal worker is likely to be older and more attached to the firm than the marginal worker. As a result, the union firm is more likely to have a pension plan and that plan is likely to have provisions which older, less mobile workers will find attractive. In particular, Freeman argues that unions are more likely to adopt a defined benefit rather than a defined contribution plan and that union plans will have stricter provisions for eligibility and portability. Under both of these provisions, persons who leave the firm subsidize those who stay. The political dominance of older workers in union politics need not result from median voter characteristics; autocracy rather than democracy may very well be a better rationale. This approach still yields the same answer to pension issues as the median voter approach - - more pensions under unionism and the adoption of pension contract provisions favorable to older workers.

Unions can also change the terms of the pension contract so as to redistribute income within and across cohorts of workers. This objective serves union interests by promoting worker solidarity and eliminating compen- 
sation cost differences as a basis for competition among employers. Standard wage rate policies help reduce income differences between older and younger workers and between skilled and unskilled workers. Their counterparts in the pension contract is the use of benefit formulas which give all workers either the same flat benefit or the same dollar amount of benefits for each year of service. Pension benefits are very rarely based on earnings in a plan covered by collective bargaining. Allen and Clark (1986) show that the impact of both earnings and years of service on pension benefits within a cohort of retirees is much smaller for union than nonunion beneficiaries. In addition, unions equalize pension wealth across cohorts by giving proportionally larger post-retirement increases to those who have been retired the longest.

Regardless of whether the pension contract is implicit or explicit, these considerations lead us to expect that collectively bargained plans will differ from nonbargained plans. A difficulty which arises in many types of implicit contracts is that in certain situations one party stands to gain from violating the contract. For instance post-retirement adjustments seem to be part of an implicit contract under which firms reduce uncertainty about the plan's rate of return and the impact of inflation in return for lower wages or lower benefits. Firms have an incentive to renege on such a contract because the worker pays for the insurance but has no legal title to claim post-retirement increases promised by the firm. In general, one would expect that firms would weigh the short-term gains from breaking the agreement against the reputational costs. Even if a firm currently faces large reputational costs for breaking implicit contracts, there still is a chance that the reputational costs will become smaller at some point in the future. 
These difficulties decrease the probability that certain types of implicit contracts will be written without some form of outside enforcement. Unions can play an important role in this regard. As long as it is in the interests of the union, it can raise the cost of violating such implicit agreements well above the cost of a diminished reputation. Since both sides recognize this, it becomes easier to write such contracts in a collective bargaining situation. Ippolito (1985c) has argued that the pension contract plays a completely different role under collective bargaining - that of a bond which the union posts to guarantee the survival of the firm. With fixed investments in physical and human capital, the firm faces the risk of a "holdup" by the union (in the form of higher wage demands or lower productivity) when it starts to receive the returns from those investments. Without some insurance against this possibility, the firm will be unable to attract capital and provide jobs for union members. Ippolito claims that underfunded pension plans provide this insurance. Under this setup, should the union ever decide to stage a holdup, its members lose the portion of their pensions which has not been funded and which is not insured by the PBGC. All parties gain from such an arrangement because holdups become unlikely, allowing the firm to make profits and the union members to collect rents.

Ippolito's model predicts that union members are more likely to be covered by pension plans than nonunion workers and that such plans are more likely to be underfunded than nonunion plans. This also means that defined contribution plans will not be adopted under unionism because such plans are by definition always fully funded. The role of past service credits for older workers in this framework is to make them more concerned about the financial wellbeing of 
the firm. The prediction about underfunding is the distinctive feature of this mode1.

In a subsequent paper, Ippolito (1986b) argues that virtually all systematic underfunding in private pension plans in the United States is attributable to underfunded plans covering unionized participants. He argues that the union tendency to "holdup" firms and the response of firms to underfund plans was one of the principal reasons for organized labor's support for passage of ERISA, including the insuring of pension benefits through the PBGC. He concludes that the resulting system provided large transfers to unionized workers. This follows from the tendency toward underfunding and the fact that the overall probability of plan sponsor failure during 1978 through 1983 was 1.4 percent while the probability for firms that were 100 percent unionized was almost 200 percent higher. PBGC data shows that almost 95 percent of the monies transferred through the pension insurance system have been claimed by union participants. Participants covered by the United Automobile Workers and the Steelworkers of America received 63 percent of these transfers.

\section{Pensions and Employee Behavior}

The characteristics of the pension contract outlined above have predictable consequences for certain types of employee behavior. It has long been recognized that pensions should and do reduce employee turnover. In the explicit contract framework, the observed correlation between pension coverage and low turnover occurs because workers who are vested in their pension receive more compensation than other workers, other things equal. In the implicit contract approach, pensions reduce turnover by imposing a tax on workers who 
leave the firm. This tax can be imposed through vesting rules which prevent workers who leave the firm before a given number of years from receiving a pension. It can also be imposed through benefit formulas based on final earnings. For instance, consider a case where a worker earns $\$ 20,000$ after 20 years and $\$ 40,000$ after 40 years in the labor market and is covered by a pension plan which will annually pay him 1.5 percent of final earnings for each year of service when he retires. If he stays at the same job throughout this period, his annual benefit will be $\$ 24,000(.015 \times 40 \times 40,000)$. However if he switches jobs after his 20 th year, his benefit will be only $\$ 18,000(.015 \times 20$ $\times 20,000+.015 \times 20 \times 40,000)$. Recognizing this, the worker becomes less likely to leave the firm because the benefit formula rewards those who stay. The incentive to stay is even greater in periods of rapid inflation because benefits are based on historical earnings unadjusted for inflation. In addition to the direct incentives which vesting and earnings-based benefit formulas provide for any employee to stay with the firm, these pension characteristics will also influence the type of employee which the firm is able to attract. Consider the following simple example. Suppose there are two types of workers with quit probabilities $p$ and $q$ respectively, with $p>q$. These differences could arise from expected differences in the value of nonmarket time over the life cycle or differences in mobility costs. A firm which must invest a great deal in worker-specific training will want to attract the worker with the lower quit probability. This can be done by setting up a compensation schedule which includes a pension with delayed vesting and an earnings based formula. This will simultaneously discourage the p-applicants and encourage the q-applicants. The result is a set of employees with lower initial odds of leaving the firm. Ex post whenever these employees 
consider leaving the firm, the financial incentives created by vesting and the benefit formula will discourage many of them from doing so. This argument is presented formally and with several interesting extensions in Viscusi (1980, 1985).

As a form of deferred compensation, pensions can also be used as part of a scheme to discourage workers from shirking. Lazear $(1979,1981)$ has showed how deferred compensation results in workers being paid less than their marginal product during their initial years with the firm and more than their marginal product in their final years. The underpayment in the initial years is equivalent to the posting of a bond for good performance. Workers who shirk must forfeit the bond as well as the ability to collect the returns to the bond in the future. This compensation scheme benefits workers because they end up with higher productivity over their lifetime and thus with more income. Lazear shows how the combination of a pension payable upon retirement and an age-earnings profile which is steeper than the age-productivity profile produces this result.

One problem which arises when firms adopt payment systems where workers receive more than their marginal product in their later years is that they have an incentive to stay with the firm too long. "Too long" in this context means that if the worker was actually paid his marginal product rather than a premium above his marginal product, he would choose to retire or work elsewhere. Lazear (1979) shows that mandatory retirement results in more efficient separation decisions by removing this adverse incentive. Pensions can also be used to encourage workers to make efficient separation decisions by acting as a form of severance pay, as shown in Lazear (1983). If the provisions for early retirement benefits are sufficiently generous, pension compensation (the 
change in pension wealth attributable to staying an extra year with the firm) becomes negative, making total compensation (earnings plus pension compensation) equal marginal product and thereby eliminating the incentive to stay "too long."

This can explain the frequent use of "sweetened" early retirement benefits in companies which must reduce employment, especially if the cost of the sweeter benefits is less than the cost of layoffs (e.g., difficulties in attracting workers in the future, higher payroll taxes). Typically, firms will offer a retirement "window", i.e. a short time period during which workers can retire under special terms. These programs often add years to a person's age and job tenure for the purpose of calculating pension benefits.

Pensions also encourage certain types of behavior which are detrimental to the firm. It is not inconceivable that pensions may reduce turnover too much. The pension loss associated with leaving a firm will keep some workers in jobs that they do not like and for which they are not well suited. This is especially likely in companies where opportunities for individual advancement turn out to be less than what employees expected.

There is also usually very little connection between pension benefits and worker performance. Pension wealth depends either on length of service or length of service and earnings. In the former case, performance affects pension wealth only to the extent that the pension discouraged the worker from engaging in behavior for which he would have been dismissed. In the latter case, the pension-performance connection depends entirely upon the linkages between earnings and performance. Unless those linkages are quite strong, the rational worker will regard pension compensation as a fixed element in the compensation package, just like health insurance and paid holidays. 
By reducing the pay differentials across different jobs within an organization, pensions limit the ability of managers to use those differentials to obtain skills needed for advancement or to use the pay system to award certain types of behavior. For instance, Allen (1981) uses a simple labor supply model to show how an increased share of employee benefits in the compensation package creates an incentive for excessive absenteeism.

Thus, the overall impact of pensions on employee behavior has both desirable and undesirable consequences for the firm. Firms with pensions should have lower turnover rates, which will save them the costs of finding and training replacements. Early retirement benefits can also be used to encourage people to leave the firm when their marginal product has fallen below their earnings. There is some risk, however, that turnover may fall too much and that many workers in the middle of their careers may stay in jobs which they do not like for fear of losing future pension benefits. Workers covered by pensions will be less likely to shirk, for fear of getting fired and losing some of the pension wealth they would have received if they had not lost their job. This is offset by the fact that the risk of getting fired is about the only linkage between pension compensation and worker performance.

\section{Regulatory Environment}

The overall impact of pensions on firm performance will be influenced by regulation. Most pension regulations deal with purely financial matters which can be ignored in the present context. Nonetheless certain pension regulations constrain the choices made by workers and firms and thus influence outcomes. At the most obvious level, pensions would be a much less popular form of compensation if they were not tax-exempt. Beyond that, the Employee Retirement Income 
Security Act of 1974 (ERISA) contains certain provisions which are likely to be relevant. First, ERISA sets minimum vesting standards. Under past regulations, most firms choose to provide complete vesting after 10 years of service. It is doubtful that this has much effect on turnover in light of the very low rates of turnover among workers with 10 or more years of service who are not covered by pensions (Allen, Clark, and McDermed (1986)). Second, ERISA makes it difficult for firms to restrict pension coverage to particular individuals. This probably has some impact on firms which are just on the margin of having a pension plan. Third, ERISA imposes limits on underfunding of pension plans and requires firms to pay for plan termination insurance. This would limit the ability of firms to use pensions to stop union holdups.

\section{Evidence on Pensions and Firm Performance}

Pensions are most likely to influence employee behavior by raising productivity and by influencing labor mobility. The impact of pensions on the overall financial well-being of the firm depends on the monetary value of these effects. It also depends upon how pensions affect the overall size of the compensation package. If there is not a dollar for dollar tradeoff (after taxes) between pensions and other forms of compensation; then firms with pensions will have higher labor costs than firms without pensions and firms with pensions will be at a competitive disadvantage, unless there is some offsetting productivity or cost differential in their favor. This section begins by summarizing previous evidence and reporting some new evidence on compensating wage differentials for pensions. The first evidence regarding the impact of pensions on productivity levels, productivity growth rates, and 
profitability is then reported. This direct evidence is inconclusive. To gain further insights, the final part of this section summarizes evidence on indirect mechanisms through which pensions can affect productivity such as turnover, retirement, and absenteeism.

\section{Compensating Wage Differentials for Pensions}

Testing for wage-pension tradeoffs has always been a very tricky business. The data sets which are usually employed by economists report wages or earnings, but they do not report pension compensation. This latter variable can be reported only by employers and even here it is not clear theoretically which concept (legal or projected earnings) of pension compensation should be used. There is a further problem with reverse causality. Workers with high earnings are also in high tax brackets and thus should want a larger share of their income in the form of pension compensation. Anyone who puts wages on the left hand side and estimated pension compensation on the right hand side of an OLS equation should not expect glowing referee reports. This problem is further exacerbated by the fact that in defined benefit plans with earnings-based formulas, pension compensation is a direct function of earnings. Lastly, it is very difficult to hold all other relevant factors constant. The critical omitted variables include other forms of compensation as well as a set of variables which will in effect hold either employee utility or firm profitability constant so that a true wage-pension tradeoff can be estimated.

A few studies have developed procedures which overcome some of these problems; their estimates are summarized in Table 6 . Out of the six studies, only two contain any evidence that wages drop by the amount of pension compensation: Schiller and Weiss (1980) got this result for the 45-54 age 
group in a 1969 sample which matched a Labor Department file of pension plan characteristics (including benefit formulas) with a Social Security earnings history file for males in those companies whose benefits were vested and Smith (1981) estimated a compensating differential for non-uniformed government workers in a sample of 58 cities and counties in Pennsylvania in 1976. The results in Schiller and Weiss for other age groups provide little in the way of additional confirmation. They find a weak negative tradeoff between wages and pensions for the 26-34 and 35-39 age groups, a weak positive tradeoff for the 40-44 age group, and no tradeoff for the 55-64 age group; all of these estimates are very imprecise. The only other study to directly test for compensating wage differentials by putting pension compensation on the right-hand side of the equation is Smith and Ehrenberg (1983), which found no evidence of a wage-pension tradeoff. The other three studies tested for such a tradeoff by using proxies for pension compensation; they also found no evidence that pensions reduce wages.

One limitation which all of these studies face is that they use individual characteristics as proxies for worker productivity. With industry data, one can include productivity directly as a right-hand side variable. This is done in Table 7, where the log of average hourly earnings for workers in 3-digit manufacturing industries in the May 1983 CPS are regressed on a set of standard control variables (hours, age, schooling, union, establishment size, tenure, marital status, race, and sex) and then a productivity measure (value added per hour) is added to the equation. In the first model, average hourly earnings are 38 percent higher in industries where all workers are covered by pensions than in industries where no workers are covered by pensions. This earnings difference drops to 35 percent when the productivity variable is 
added to the model. Thus, adding productivity to the set of right-hand side variables does not shed any new insights. Equations estimated over full time private wage and salary workers in the May 1983 CPS produce sharply lower estimates of the wage premium which workers with pensions receive (16 to 19 percent) This suggests that aggregation may be contaminating the estimates obtained from industry data, but it is clearly not creating enough bias to reverse the direction of the estimate.

In summary, the empirical evidence on wage-pension tradeoffs is quite clear. Most estimates of compensating wage differentials for pension coverage show that wages do not drop dollar-for-dollar with increases in pension compensation. Firms with pensions pay higher compensation to their current workers. Thus, the empirical studies suggest that firms must have higher productivity or receive some cost savings elsewhere in order to survive in markets with firms which do not have pensions. of course, another plausible explanation is that these studies have been unable to accurately estimate the true pension compensating wage differential. A final conclusion on the magnitude of any compensating differential awaits better theory or better data.

\section{Pensions. Productivity and Profits}

As pointed out in Section V, pensions can potentially increase productivity by reducing turnover and shirking and by producing efficient retirement decisions. These positive effects may be offset by excessively low turnover rates, higher absenteeism, and the weaker linkage between performance and pay that is generated by many pension plans. To determine whether pensions do have any impact on productivity, we merged data for 3-digit manufacturing industries from the 1983 Annual Survey of Manufacturers (ASM) with pension 
coverage data for those industries from the May 1983 CPS. The production function is assumed to be Cobb-Douglas with constant returns to scale. The productivity measure is the $\log$ of value added per hour. It is regressed on the $\log$ of the capital-labor ratio and the fraction of workers in each industry who participate in an employer or union sponsored pension plan, along with a set of 20 binary variables indicating 2 -digit industry. We also included a set of six additional control variables: ratio covered by union contracts, ratio in establishments with fewer than 25 employees, ratio with less than one year of service with their employer (new hires), average years of schooling, and average age. After experimenting with a variety of specifications, we found that the impact of pension coverage on productivity varied with union contract coverage, average age, and the share of employees who are new hires. Thus, we added interaction terms between each of these variables and pension coverage. To estimate the impact of the size of pension benefits on productivity, we also included an interaction term between pension coverage and the log of average hourly earnings. The results are reported in Table 8 with and without the interaction terms.

In the specification without interaction terms (column 1 in Table 8), productivity is 25.3 percent lower in industries with high pension coverage rates, but the impact of pension coverage is not statistically different from zero. In fact, productivity is uncorrelated with most variables in the model, except for the capital-labor ratio and average weekly hours.

The results for the specification containing the interaction terms show a much more complex relationship between productivity, pension coverage, and the other right hand side variables. The impact of pension coverage on productivity clearly varies with average hourly earnings, union contract 
coverage, average age of workers, and the share of workers who are new hires. Pensions are more likely to have a positive impact on productivity in industries with high earnings, a small share of workers covered by union contracts, a small ratio of new hires to employment, or a large share of young workers. At the across-industry means of these variables, productivity is 35.3 percent lower in industries where all workers are covered by pensions than in industries where no workers are covered. Pension coverage is correlated with greater productivity in industries where union contract coverage is below 12.6 percent, where fewer than 6.8 percent of all employees are new hires and where coverage age is below 35.4 percent. (The across-industry means of these variables are 30.5 percent, 14.1 percent, and 38.5 percent). On balance, these results show that in the average industry pensions have no effect on productivity, but pensions are associated with hither productivity in nonunion industries with low new hire rates, high wages, and younger workers.

A related measure of firm performance is productivity growth. In most studies of productivity growth done by economists, the focus is usually on the impact of such variables as research intensity, concentration ratios, and collective bargaining. The impact of human resources policies on innovative activity has not been carefully explored. To the extent that pensions help mold long term economic security among the workforce, they may also encourage innovation.

The Labor Department calculates productivity growth indexes for a set of 4-digit industries where output can be measured in physical units. The ratio of the 1983 to the 1972 values of the productivity index was regressed on pension coverage to estimate the impact of pension coverage on productivity growth and the results are shown in Table 9. Pension coverage data from the 
beginning of the period are unavailable. To establish the robustness of the findings, we constructed pension coverage rates by 3 -digit industry from the 1979 as well as the 1983 May CPS. Also included as control variables were percentage union members in 1973-75, the change in unionization between 1973-75 and 1984, the 1972 four firm concentration ratio, the difference between the 1982 and the 1972 concentration ratio, and the ratio of $R \& D$ used by the industry to value added. The sample consists of 73 industries.

When pension coverage in 1983 appears on the right-hand side of the equation, 1972-1983 productivity growth is 32 percentage points greater in industries where workers are covered by pensions than in industries where workers are not covered. However, this estimate is barely larger than its standard error. Further, when 1979 coverage rates are used instead, there is no correlation between pension coverage and productivity growth. Productivity growth is faster in industries which are concentrated, in industries where concentration ratios are rising, and in industries with high ratios of $R \& D$ to output. Pension coverage does not seem to affect productivity growth.

The final indicator of the impact of pensions on firm performance which we examined was profitability. This variable can be measured in the 1983 ASM data in two different ways. Profits equal value added less depreciation, total payroll (including benefits and Social Insurance), and rental capital. The estimated rate of return on assets equals profits divided by the gross book value of capital at the end of the year. The price cost margin equals profits divided by value added. Both variables were regressed on the same sets of control variables which were used in the productivity level equations in Table 8 and the results are reported in Table 10. 
Industries with high pension coverage rates seem to have the same profit rates as industries with low coverage rates. In the specifications without pension interactions (columns 1 and 3), each profit measure is 12 to 13 percentage points higher when all workers are covered by pensions than when none are, but neither estimate is significantly different from zero. When the interaction terms with pension coverage are added in columns 2 and 4, the average rate of return on assets is 4 percentage points lower in the average industry if it has full pension coverage than if it has no pension coverage, whereas the price-cost margin is 8 percentage points higher if it has full pension coverage. Neither estimate is statistically significant. Except for the age interaction in the rate of return equation, the signs of the interaction terms in both profit equations are the same as in the productivity equations. Thus, the profit equations also indicate that pensions are more likely to enhance firm performance in nonunion industries with relatively few new hires and a younger workforce.

Profit rates should be lower in industries with high coverage rates if pensions raise labor costs but do not raise productivity. Why are these results contradictory? The first suspect is always the data, in this case the ASM data used to estimate the productivity and profit equations. In the data's defense, we note that there was a very strong positive correlation between productivity and the capital-labor ratio and that the coefficient of the capital-1abor ratio was always near capital's share of output in manufacturing (all coefficients were between .42 and .44). Perhaps the pension coverage rates from the CPS contained too much measurement error, but restrictions on the sample to industries were more than 30 observations for each 3 -digit 
industry cell did not affect the results. This leads us to believe that the data are not the problem.

Another possibility is the empirical model. We used pension coverage but could not take into account variation in the size of pension compensation across different industries. Based on our studies of pension benefit formulas across different industries, we find it hard to believe that this is contaminating our results. Benefit parameters do not vary all that much among manufacturing firms with common formula types. Differences in other pension characteristics, such as age of eligibility for early or normal benefits, may be important in this regard, but study of any of these questions awaits better data.

One final way to resolve this contradiction is to examine variables which are believed to affect productivity, although the exact magnitude of their impact is unknown. We do this in the final part of this section, focusing on the evidence on pensions and turnover.

\section{Indirect Evidence on Pensions and Productivity}

All of the available evidence shows that pensions reduce turnover. Mitchell (1982) tested the effect of pension coverage on quits and job changes using the longitudinal sample from the 1973 and 1977 Quality of Employment Survey. She found that men were 10 percent less likely to quit if they were covered by a pension plan. Pension coverage had a smaller and statistically insignificant effect on quits among females. Job changes were much less likely to occur among both males and females covered by a pension. Taking into account the simultaneity between wage offers and quits, Mitchell (1983) obtains similar results: pension coverage lowers the quit rate for males but has no significant 
effect on the quit rate for females. The impact of pensions on mobility has also been studied over a sample of United Kingdom data by McCormick and Hughes (1984). They also find that pensions reduce mobility.

This still leaves open the question of why pensions reduce mobility. One factor which has always been thought to be important is vesting. A worker who is considering leaving a company may remain with the firm longer than he would otherwise in order to receive a pension. The impact of vesting on turnover depends on how much pension wealth is obtained at vesting. The available evidence indicates that for most workers this gain is fairly small. Looking across 1183 plans in the BLS 1979 Level of Benefits survey, Kotlikoff and Wise (1985) show that the gain in pension wealth when vesting occurs at age 40 ranges between 5 and 37 percent of salary. At their intermediate wage and interest rate assumptions, the gain is 14 percent. For most workers this amounts to a few thousand dollars. This will be of critical importance to a worker with 9 years of service who can move from zero to full vesting by staying an additional year. It is not likely to have much effect on workers with less than five years of service, the group where turnover is most likely to take place. The only empirical evidence on this issue comes from a study of persons covered by 133 pension plans done by Schiller and Weiss (1979). They found that stricter vesting requirements were associated with higher exit rates. Thus, both theory and evidence indicate that vesting is not likely to explain why pensions reduce turnover.

There are three other possibilities. First, lower mobility rates for workers covered by pensions may merely reflect a higher overall level of compensation. Most studies include either actual or imputed wages as control variables, so it should be no real surprise that they find a positive correla- 
tion between pension coverage and mobility. Workers covered by pensions have higher total compensation than other workers ceteris paribus. A second possible explanation is that pension benefit formulas are structured so that there is a capital loss for those leaving the firm. As noted above, this can only happen if the pension is part of an implicit labor contract. Under the legal or explicit contract interpretation of the value of pension wealth, there is no penalty for turnover. The final possibility is that the lower mobility observed among workers covered by pensions reflects the use of pensions as a sorting device. Workers who expect to stay with a firm are attracted to firms which provide pensions; those who do not intend to stay prefer a different compensation structure.

One can distinguish between these three explanations by focusing on the coefficients of pension coverage, pension compensation, and the capital loss associated with mobility. Under the first explanation, once pension compensation is added to the model, pension coverage should no longer be correlated with mobility. If it is only greater compensation which ties workers around to jobs with pensions, then the pension compensation variable will be a much more accurate measure of the extra value of those jobs than the coverage dummy. The validity of the second explanation depends on the correlation between the capital loss and turnover. If the third explanation is correct, then the coverage dummy will still be a good predictor of turnover but pension compensation and the capital loss will be uncorrelated with turnover.

Allen, Clark, and McDermed (1986) examined the validity of each of these by estimating length of service and mobility equations over three different data sets; the results are summarized in Table 11 . In every data set pension coverage is a very strong predictor of length of service and turnover, even 
when the pension compensation and the capital loss variables are included in the model. Also, except for the years of service equations estimated over the May 1983 CPS (all spells in progress), pension compensation has no effect on mobility or length of service. Both of these findings clearly contradict the first explanation.

The results for the capital loss variable vary across each sample. In both the CPS and the Panel Survey of Income Dynamics (PSID) the capital loss was strongly related to years of service. It was also correlated with lower job change probabilities for workers between the ages of 45 and 54 in the PSID. However, the capital loss had no effect on mobility for workers under the age of 45 in the PSID, nor did it have any effect on mobility in the National Longitudinal Survey (NLS) sample of older men.

A likely explanation for the negative findings on mobility for younger workers is that the mean of capital loss of pension wealth per year of remaining worklife is rather small. It is $\$ 36$ for workers covered by pensions who are less than 25 years old; $\$ 143$ for between 25 and 34 ; and $\$ 335$ for those between 35 and 44. In contrast the average loss for workers between 45 and 54 is $\$ 590$. Thus the loss may not have very much effect on workers under 45 because the loss is not very big.

This rationale does not apply to the workers in the NLS sample, where the mean loss per year of remaining worklife is $\$ 1270$. The key factor here is probably the very low mobility rate in the sample. The average age of workers in the sample in 1971 is 56 and only 17 percent of them change jobs over a ten year period. Among those covered by pensions the mobility rate is an even smaller 9 percent. Thus the capital loss may have little effect on mobility 
because a negligible proportion of older workers covered by pensions change jobs.

The results also support the self selection argument. Self selection is clearly not the only factor, as the capital loss results indicate. Yet neither the capital loss variable nor the pension compensation variable can account for the lower turnover observed among younger workers covered by pensions. Self selection is the only remaining explanation for this group.

An estimate of the impact of this decline in turnover on productivity can be obtained by using the result in Brown and Medoff (1978) that a decline of the $\log$ of the annual quit rate equal to one results in an 11 percent increase in productivity. Based on the PSID sample means, it seems reasonable to us that pensions reduce turnover from about 4 percent per year to 2 percent. This translates into a $\log$ change of -.69 which is associated with a productivity increase of about 7.6 percent.

In addition to turnover, indirect evidence on the effect of pensions on productivity can be obtained from studies of work attendance and retirement. Allen (1981) found in a sample of 41 paper and box manufacturing plants that a 10 percent increase in monthly pension benefits per year of service is associated with an increase in the absence rate of 0.2 percentage points (the mean absence rate was 2.5 percent). This evidence is consistent with the theory that workers consider income from benefits as exogenous in making labor supply decisions and that increases in exogenous income reduce the number of hours which employees desire to work.

The survey article by Mitchell and Fields (1982) indicates that most studies find higher pensions tend to encourage earlier retirement. Further 
evidence in support of this conclusion appears in more recent studies by Fields and Mitche11 (1984) and Allen and Clark (1986).

The implications of these findings for productivity are not clear. Some studies have indicated that the effect of age on productivity is insignificant prior to age 60 or older. When productivity begins to decline (whether due to changes in technology, depreciation of human capital, or changes in mental or physical abilities), this need not translate into a drop in job performance. 01der workers may be able to adjust by having lower absence rates, lower turnover rates, or increased quality of work. Reviews of studies concerning the age-productivity relationship are provided by Clark and Spengler (1980), Kreps (1977) and Riley and Foner (1968). In examining productivity by age, it is also important to recognize that only workers who remain employed are included in the measured population. The least productive workers may have already quit or been fired, in which case earlier retirement of the remaining workers may not be in the firm's best interests. Much needs to be learned about these issues.

\section{Observations and Conclusions}

The role of pensions as a form of compensation and as a method of achieving personnel objectives has received substantial attention by economists over the last decade. The rapid growth and now widespread use of employer-provided pensions suggests that offering a pension as a form of compensation does not adversely affect the economic performance or the profitability of firms. Coverage rates vary significantly across industrial and occupational groups; however, no sector has 100 percent coverage or zero coverage of workers by 
pensions. Thus, firms with and without pensions coexist side by side in many different types of markets.

We have presented the first empirical evidence that the rate of profits among firms is not affected by the existence of a pension. Obviously, pensions cost the firm money but if they do not reduce profits then there must be some compensating offsets either through a reduction of other labor costs or through an increase in productivity. A brief review of existing studies of compensating wage differentials attributable to pensions yields inconclusive results. At best, we can conclude that there is no empirical basis for arguing that wages or other forms of compensation decline in the presence of a pension. This does not necessarily imply that there are no compensating wage differentials for pension benefits; it merely means that there is presently little empirical evidence of such differentials. We provide the first estimates of the direct effect of pensions on labor productivity and are unable to find any significant effect of pension coverage on productivity within industries while holding constant average worker and firm characteristics.

If all of these findings are correct, how do firms offering pensions compete with firms that do not provide this form of compensation? There are two possibilities. First, the evidence seems to indicate that the answer is indirect productivity effects. Instead of being neutral sellers of pensions to workers, firms use pensions to achieve personnel objectives. These objectives are to reduce turnover during most of the employee's worklife and to increase retirement rates among older workers. Lower turnover means fewer resources are devoted to hiring and training new workers. It increases the proportion of workers with a greater amount of job tenure and on the average this raises labor productivity. Earlier retirement among older workers may reduce average 
salaries and also may affect average productivity of workers. The second possibility is that the empirical results are misleading, particularly those on compensating wage differentials.

These changes in the age-tenure composition of the labor force and their effect on productivity are not captured in the productivity regressions discussed above. It seems likely that they provide the solution to our puzzle. Furthermore, these effects may provide an explanation for the pattern of pension coverage across firms. Firms with greater costs of turnover should be more likely to offer pensions. Firms in which workers suffer greater productivity declines with advancing age should be more likely to offer pensions. Since these are different objectives, some firms may wish to discourage turnover but not encourage earlier retirement. These firms should have different plan characteristics than firms which seek to encourage early retirement.

Many of the conclusions concerning pensions and firm performance are quite tentative and must await further confirmation. Past studies have been hindered by a lack of data that relates plan features and the characteristics of sponsoring firm to worker characteristics. The 1983 Survey of Consumer Finance may be helpful in this regard but it does not allow the researcher to determine the productivity and profitability of the firm. We anticipate continued progress in the estimation of the effect of pensions on mobility and retirement decisions. A greater knowledge of these effects and a better understanding of the link between age, tenure and productivity would significantly increase our understanding of the relationship between pensions and firm performance. It would be useful to have a theory of the optimal age structure of a firm and how pensions can be used to achieve this objective. 
One element of the relationship between pensions and firm performance which this study has not addressed is the impact of the financial status of the pension plan. Studies of market valuation done by Feldstein and Seligman (1981), Feldstein and Morck (1983), and Bulow, Morck, and Summers (1985) all indicate that the stock market treats net assets in a pension plan as if they were part of the corporate balance sheet. In other words, underfunded pension plans translate into a lower market value of the firm's stock, with the decline in market value equal to the funding liability.

The recent decline in interest rates and the accompanying bull market have put most pension plans on excellent financial footing. A growing number of plans are being terminated with the excess assets reverting to the firm. In most cases, a new pension plan is created after a termination which preserves the legal pension wealth of both participants and annuitants. It remains to be seen whether their wealth under the implicit contract interpretation of the firm's pension promises will also be preserved and, if not, what impact this will have on employee behavior. 
Table 1. Determinants of Pension Coverage, $1983 \mathrm{CPS}^{\mathrm{a}}$

\begin{tabular}{|c|c|c|}
\hline $\begin{array}{l}\text { Per } \\
\text { cov } \\
\text { per }\end{array}$ & $\begin{array}{l}\text { centage } \\
\text { ered by } \\
\text { sion }\end{array}$ & $\begin{array}{l}\text { Marginal impact on } \\
\text { pension coverage } \\
\text { probability from } \\
\text { probit equation }(x \quad 100)\end{array}$ \\
\hline \multicolumn{3}{|l|}{ Union contract coverage } \\
\hline Nonunion & 44.1 & -- \\
\hline Union & 82.2 & 26.3 \\
\hline \multicolumn{3}{|l|}{ Establishment size } \\
\hline Less than 25 & 27.8 & -- \\
\hline $25-99$ & 51.1 & $2.4 x$ \\
\hline $100-499$ & 68.9 & 4.7 \\
\hline $500-999$ & 77.6 & 9.6 \\
\hline 1000 or more & 85.9 & 10.2 \\
\hline \multicolumn{3}{|l|}{ Company size } \\
\hline Less than 25 & 17.1 & -- \\
\hline $25-99$ & 36.7 & 15.1 \\
\hline $100-499$ & 54.6 & 26.5 \\
\hline $500-999$ & 62.7 & 31.1 \\
\hline 1000 or more & 79.7 & 45.2 \\
\hline \multicolumn{3}{|l|}{ Industry } \\
\hline Agriculture, forestry, fisheries & 11.3 & $4.0 *$ \\
\hline Mining & 74.0 & 14.4 \\
\hline Construction & 35.9 & -11.0 \\
\hline Durable manufacturing & 72.2 & 9.2 \\
\hline Nondurable manufacturing & 64.7 & 6.2 \\
\hline Transportation and utilities & 70.8 & $2.2 \star$ \\
\hline Wholesale trade & 52.1 & 11.6 \\
\hline Retail trade & 31.7 & $-3.5 *$ \\
\hline Finance, insurance, real estate & 58.8 & 10.7 \\
\hline Services & 39.6 & -- \\
\hline \multicolumn{3}{|l|}{ Occupation } \\
\hline $\begin{array}{l}\text { Executive, administrative, } \\
\text { managerial }\end{array}$ & 60.2 & -- \\
\hline Professional specialty & 61.6 & $0.1 *$ \\
\hline Technicians \& related support & 60.0 & $-3.0 *$ \\
\hline Sales & 42.6 & -6.0 \\
\hline $\begin{array}{l}\text { Administrative support, } \\
\text { including clerical }\end{array}$ & 55.8 & $3.4 *$ \\
\hline Private household service & 0.0 & -- \\
\hline Protective service & 37.7 & -17.7 \\
\hline Other service & 27.6 & -8.9 \\
\hline $\begin{array}{l}\text { Precision production, } \\
\text { craft \& repair }\end{array}$ & 57.4 & $-1.3 *$ \\
\hline $\begin{array}{l}\text { Machine operators, assemblers } \\
\& \text { inspectors }\end{array}$ & 59.5 & $-4.7 *$ \\
\hline $\begin{array}{l}\text { Transporation \& material } \\
\text { moving }\end{array}$ & 53.7 & $-3.6 *$ \\
\hline
\end{tabular}


Table 1. Determinants of Pension Coverage, 1983 CPS $^{a}$ (cont'd)

\begin{tabular}{|c|c|c|}
\hline & $\begin{array}{l}\text { Percentage } \\
\text { covered by } \\
\text { pension }\end{array}$ & $\begin{array}{l}\text { Marginal impact on } \\
\text { pension coverage } \\
\text { probability from } \\
\text { probit equation }(x 100)\end{array}$ \\
\hline $\begin{array}{l}\text { Handlers, equipment } \\
\text { cleaners, etc. }\end{array}$ & 47.2 & $-3.4 *$ \\
\hline Farming, forestry \& fishing & 11.1 & -17.2 \\
\hline Region & & \\
\hline Northeast & 57.5 & 7.8 \\
\hline North Central & 58.0 & 10.9 \\
\hline South & 47.5 & 5.0 \\
\hline West & 47.4 & -- \\
\hline \multicolumn{3}{|l|}{ Sex } \\
\hline Female & 45.6 & $-\ldots$ \\
\hline Male & 56.8 & 3.4 \\
\hline \multicolumn{3}{|l|}{ Marital Status } \\
\hline Married, spouse present & 57.6 & 2.9 \\
\hline Other & 42.2 & -- \\
\hline \multicolumn{3}{|l|}{ Age } \\
\hline $16-24$ & 26.0 & $-\ldots$ \\
\hline $25-34$ & 50.5 & 13.4 \\
\hline $35-44$ & 61.2 & 20.4 \\
\hline $45-54$ & 62.2 & 24.3 \\
\hline $55-64$ & 62.8 & 24.0 \\
\hline \multicolumn{3}{|l|}{ Years of schooling } \\
\hline Less than 9 & 43.6 & $\ldots$ \\
\hline $9-11$ & 44.4 & $1.8 *$ \\
\hline 12 & 52.0 & 7.8 \\
\hline $13-15$ & 52.0 & 7.0 \\
\hline 16 & 57.2 & $4.8 *$ \\
\hline More than 16 & 66.6 & 10.1 \\
\hline \multicolumn{3}{|l|}{ Average hourly earnings } \\
\hline Less than $\$ 4$ & 13.2 & $\ldots$ \\
\hline$\$ 4-\$ 5.99$ & 31.8 & 17.6 \\
\hline$\$ 6-\$ 7.99$ & 51.8 & 28.6 \\
\hline$\$ 8-\$ 9.99$ & 63.2 & 32.9 \\
\hline$\$ 10-\$ 14.99$ & 73.3 & 37.4 \\
\hline$\$ 15$ or more & 79.4 & 41.2 \\
\hline
\end{tabular}

${ }^{a_{S a m p l e}}$ is limited to private wage and salary workers between the ages of 16 and 64 who usually work more than 35 hours per week. The estimates in the second column are probit estimates of the derivative of the probability function evaluated at the means of the independent variables. All of the above variables were included in the probit equation. Estimates with a significance level below the 95 percent level are indicated with an asterisk. 
Table 2. Percent Defined Contribution Coverage Among Pension-Covered Workers, 1982

Pension Plan Size

Union

Nonunion

(Participants)

$\begin{array}{crr}1-99 & 12.9 & 63.1 \\ 100-999 & 4.3 & 31.2 \\ 1,000-10,000 & 3.6 & 11.2 \\ \text { Greater than } 10,000 & .7 & 4.9 \\ \text { Total } & 2.0 & 22.4\end{array}$

Source: Richard Ippolito, "A Study of the Regulatory Impact of ERISA," unpublished paper, July 1986, Table 4. 
Table 3. Post Retirement Increases in Pension Benefits

$\begin{array}{ll} & \frac{\text { Union }}{\text { Benefits as }} \\ \text { Percent Awarded } & \text { Percent of } \\ \text { Increase } & 1973 \text { Benefit }\end{array}$

\begin{tabular}{ll} 
& Nonunion \\
& Benefits as \\
Percent Awarded & Percent of \\
Increase & 1973 Benefit \\
\hline
\end{tabular}

1973

45.0

100.0

25.6

100.0

1974

59.6

105.6

31.6

101.3

1975

62.2

110.3

35.6

105.1

1976

52.6

114.7

19.1

108.9

1977

60.4

119.4

42.9

110.3

1978

65.6

123.2

11.4

117.2

1979

128.6

118.5

Change 1973-79

28.6

18.5

Source: Robert Clark, Steven Allen, and Daniel Sumner, "Inflation and Pension Benefits," in Richard Ippolito and Walter Kolodrubetz (Eds.) The Handbook of Pension Statistics 1985, Chicago: Commerce Clearing House, 1986, p. 196. 
Table 4. Earnings and Pension Compensation by Age and Tenure ${ }^{a}$

Total Compensation

\begin{tabular}{lccccc} 
Age & Tenure & Earnings & $\begin{array}{l}\text { Pension } \\
\text { Compensation }\end{array}$ & $\begin{array}{l}\text { Percent } \\
\text { Earnings }\end{array}$ & $\begin{array}{c}\text { Percent Pension } \\
\text { Compensation }\end{array}$ \\
\hline 30 & 10 & $\$ 7,743$ & $\$ 321$ & 96.0 & 4.0 \\
35 & 15 & 8,891 & 456 & 95.1 & 4.9 \\
40 & 20 & 10,174 & 663 & 93.9 & 6.1 \\
45 & 25 & 11,606 & 957 & 92.4 & 7.6 \\
50 & 30 & 13,189 & 1,374 & 90.6 & 9.4 \\
55 & 35 & 14,914 & 1,969 & 88.3 & 11.7 \\
60 & 40 & 16,753 & 2,820 & 85.6 & 14.4 \\
64 & 44 & 18,262 & 3,767 & 82.9 & 17.1 \\
65 & 45 & 22,796 & -106 & 100.5 & -0.5 \\
70 & 50 & 30,118 & $-3,814$ & 114.5 & -14.5 \\
\hline
\end{tabular}

${ }^{a}$ The analysis is based on a defined benefit plan with an earnings based formula. Salary average is computed over the last 5 years of earnings and the generosity parameter is 1.0 percent per year of service.

Source: Robert Clark and Ann McDermed, "Earnings and Pension Compensation: The Effect of Eligibility," Quarterly Journal of Economics XCXI (1986): 341-61. 
Table 5. Lifetime Compensation (Projected Earnings Method): Manufacturing, Professional and Administrative Workers, 1,000 or More Employees a

\begin{tabular}{lcccccc} 
Age & Tenure & Earnings & $\begin{array}{l}\text { Pension } \\
\text { Compensation }\end{array}$ & $\begin{array}{l}\text { Total } \\
\text { Compensation }\end{array}$ & $\begin{array}{l}\text { Pension } \\
\text { Wealth }\end{array}$ & $\begin{array}{l}\text { Pension } \\
\text { Loss From } \\
\text { Leaving }\end{array}$ \\
\hline 25 & 0 & 8,839 & 1,161 & 10,000 & 0 & 0 \\
35 & 10 & 11,866 & 1,573 & 13,439 & 15,728 & 8,921 \\
40 & 15 & 13,744 & 1,835 & 15,580 & 27,529 & 13,727 \\
45 & 20 & 15,912 & 2,150 & 18,061 & 42,990 & 18,029 \\
50 & 25 & 18,398 & 2,540 & 20,938 & 63,492 & 20,833 \\
55 & 30 & 21,231 & 3,042 & 24,273 & 91,259 & 20,416 \\
60 & 35 & 24,428 & 3,711 & 28,139 & 129,870 & 13,661 \\
64 & 39 & 31,448 & 222 & 31,670 & 173,174 & 0 \\
65 & 40 & 32,809 & -188 & 32,620 & 181,514 & 0 \\
70 & 45 & 43,873 & $-6,057$ & 37,816 & 227,394 & 0 \\
\hline
\end{tabular}

${ }^{a}$ The analysis is based on the average plan in manufacturing for professional workers. The plan is a defined benefit plan with an earnings based formula. Average salary is computed over the last 5 years of earnings and the generosity parameter is 1.53 percent per year of service.

Source: Steven Allen, Robert Clark, and Ann McDermed, "Job Mobility, Older Workers, and the Role of Pensions," Final Report for U.S. Department of Labor Contract No. J-9-M-5-0049, October 1986. 
Table 6. Previous Evidence on Wage-Pension Tradeoffs

\begin{tabular}{|c|c|c|}
\hline Study & Sample & $\begin{array}{c}\text { Key } \\
\text { Results }\end{array}$ \\
\hline
\end{tabular}

Direct tests

Schiller and Weiss (1980)

1969 Labor Dept. private pension file match with SSA earnings histories; males in defined benefit plans

Coefficient of legal method pension compensation in $\log$ earnings equation is -1 for 45-54 age group but no wagepension tradeoff for other four age graus

Smith (1981)

1976 Pennsylvania non-uniformed government workers in defined benefit plans

Smith and Ehrenberg (1983) 200 firms providing pension and earnings data to Hay Associates

Coefficient of legal method pension compensation in $\log$ earnings equation is -1

Earnings difference across Hay Point levels within firms uncorrelated with either difference in pension value or difference in pension costs

Indirect tests

Ehrenberg (1980)

1973 data on police and firefighters

Fntrance pay and maximm earnings inversely related to ratio of benefits to earnings to earnings for police; no correlation for firefighters

1974-75 data an police, firefighters, and sanitation workers

Clark and McDermed (1986a) 1971-75 Retirement History Survey; full-time males

Average ammual earnings uncorrelated with ratio of benefits to earnings

Earnings significantly higher for those working past age of pension eligibility to offset drop in pension compensation

Mitchell and Pozzebon (1986) 1983 Survey of Consumer Finance; private nonagricultrual wage and salary employees

Log hourly wage significantly higher for those covered by either defined benefit or defined contribution plans

Source: Olivia Mitchell, and Silvana Pozzebon, "Wages, Pensions and the Wage-Pension Tradeoff," umpublished paper, 1986. 
Table 7. Log Average Hourly Earnings Equation Estimates

\begin{tabular}{lll}
$\begin{array}{l}\text { Sample and pension } \\
\text { variable }\end{array}$ & $\begin{array}{l}\text { Additional } \\
\text { controls }\end{array}$ & $\begin{array}{l}\text { Pension cover } \\
\text { coefficient }\end{array}$ \\
\hline $\begin{array}{l}\text { 3-digit manufacturing } \\
\text { industries, 1983 Annual } \\
\text { Survey of Manufacturers }\end{array}$ & & \\
$\quad \begin{array}{l}\text { Percentage participating } \\
\text { in pension plan }\end{array}$ & List 1 & .319 \\
$\quad \begin{array}{l}\text { Percentage participating } \\
\text { in pension plan }\end{array}$ & $\begin{array}{l}\text { List 1, log of } \\
\text { value added per hour }\end{array}$ & $(.079)$ \\
$\begin{array}{l}\text { Ful1-time private wage } \\
\text { and salary workers, May } \\
\text { 1983 CPS: }\end{array}$ & & .301 \\
$\begin{array}{l}\text { Participates in } \\
\text { pension plan }\end{array}$ & & \\
$\quad \begin{array}{l}\text { Employer provides } \\
\text { pension plan }\end{array}$ & List 2 & $(.009)$ \\
\end{tabular}

List 1: Average weekly hours, average age, average years of schooling completed, percentage covered by union contracts, percentage in small establishments, percentage with less than one year of service, percentage married, percentage white, percentage male

List 2: Age, years of schooling completed, union contract coverage, sex, marital status, establishment size, firm size, region, industry, occupation 
Table 8. Productivity Equation Estimates, 1983 ASM 3-digit Industries

(1)

$\ln (K / L)$

Ratio covered

by union contracts

atio in establishments

with fewer than 25 people

Ratio with less than

one year of service

Average age

Average years of

schooling completed

Average weekly hours

Ratio covered by pension

Pension * average $\ln (w)$

Pension * union

Pension * new hires

Pension * age

$\mathrm{R}^{2}$
.427

$(.037)$

$-.078$

$(.207)$

$-.360$

$(.217)$

$-.173$

$(.446)$

$-.001$

$(.010)$

$-.027$

(.034)

.034

$(.016)$

$-.292$

(.242)

(.242)
.789

$-2.463$

(1.190)

$-5.974$

(2.884)

$-.142$

$(.059)$

.807 
Table 9. Productivity Growth Equation Estimates, 4-digit Industries 1972-1983a

(1)

Constant

Pension coverage 1983

Pension coverage 1979

Percentage union

1973-75

Change in percentage union 1973-75 to 1984

Concentration ratio 1972

Change in

concentration ratio

1972 to 1982

$R \& D$ intensity

$\mathrm{R}^{2}$

$\begin{array}{ll}.763 & .884 \\ (.181) & (.223)\end{array}$

.317

$(.316)$

$-.026$

$(.424)$

$-.039$

(.298)

.164

$(.344)$

$-.764$

$-.649$

$(.530)$

(.553)

.344

.417

(.157)

(.157)

1.288

(.499)

1.226

(.500)

1.160

(.576)

1.187

(.583)

.234

.222

astandard errors appear in parentheses 
Table 10. Rate of Return and Price-Cost Margin Equation Estimates, 1983 ASM 3-digit Industries ${ }^{a}$

\begin{tabular}{|c|c|c|c|c|}
\hline & \multicolumn{2}{|c|}{$\begin{array}{l}\text { Rate of return } \\
\text { on assets }\end{array}$} & \multicolumn{2}{|c|}{$\begin{array}{l}\text { Price-cost } \\
\text { margin }\end{array}$} \\
\hline & (1) & (2) & (3) & (4) \\
\hline $\ln (K / L)$ & $\begin{array}{l}-.407 \\
(.085)\end{array}$ & $\begin{array}{l}-.426 \\
(.086)\end{array}$ & $\begin{array}{l}-.004 \\
(.016)\end{array}$ & $\begin{array}{l}-.009 \\
(.015)\end{array}$ \\
\hline $\begin{array}{l}\text { Ratio covered by } \\
\text { union contracts }\end{array}$ & $\begin{array}{l}-.368 \\
(.477)\end{array}$ & $\begin{array}{l}.855 \\
(2.134)\end{array}$ & $\begin{array}{l}-.117 \\
(.089)\end{array}$ & $\begin{array}{l}.446 \\
(.377)\end{array}$ \\
\hline $\begin{array}{l}\text { Ratio in establishments } \\
\text { with fewer than } 25 \text { people }\end{array}$ & $\begin{array}{l}-.355 \\
(.499)\end{array}$ & $\begin{array}{l}-.438 \\
(.516)\end{array}$ & $\begin{array}{l}.052 \\
(.093)\end{array}$ & $\begin{array}{l}.010 \\
(.091)\end{array}$ \\
\hline $\begin{array}{l}\text { Ratio with less than } \\
\text { one year of service }\end{array}$ & $\begin{array}{c}.742 \\
(1.027)\end{array}$ & $\begin{array}{l}7.273 \\
(5.017)\end{array}$ & $\begin{array}{l}.212 \\
(.191)\end{array}$ & $\begin{array}{l}2.827 \\
(.887)\end{array}$ \\
\hline Average age & $\begin{array}{l}.007 \\
(.024)\end{array}$ & $\begin{array}{l}.136 \\
(.100)\end{array}$ & $\begin{array}{l}-.004 \\
(.004)\end{array}$ & $\begin{array}{l}.048 \\
(.018)\end{array}$ \\
\hline $\begin{array}{l}\text { Average years of } \\
\text { schooling completed }\end{array}$ & $\begin{array}{l}-.045 \\
(.078)\end{array}$ & $\begin{array}{l}-.106 \\
(.100)\end{array}$ & $\begin{array}{l}-.004 \\
(.014)\end{array}$ & $\begin{array}{l}-.011 \\
(.018)\end{array}$ \\
\hline Average weekly hours & $\begin{array}{l}.066 \\
(.037)\end{array}$ & $\begin{array}{l}.062 \\
(.037)\end{array}$ & $\begin{array}{l}.007 \\
(.007)\end{array}$ & $\begin{array}{l}.006 \\
(.006)\end{array}$ \\
\hline Ratio covered by pension & $\begin{array}{l}.129 \\
(.557)\end{array}$ & $\begin{array}{l}6.978 \\
(6.504)\end{array}$ & $\begin{array}{l}.119 \\
(.104)\end{array}$ & $\begin{array}{l}3.198 \\
(1.150)\end{array}$ \\
\hline Pension $*$ average $\ln (w)$ & & $\begin{array}{c}.827 \\
(.813)\end{array}$ & & $\begin{array}{l}.202 \\
(.144)\end{array}$ \\
\hline Pension $*$ union & & $\begin{array}{l}-1.818 \\
(2.809)\end{array}$ & & $\begin{array}{l}-.803 \\
(.497)\end{array}$ \\
\hline Pension * new hires & & $\begin{array}{l}-8.725 \\
(6.805)\end{array}$ & & $\begin{array}{l}-3.482 \\
(1.203)\end{array}$ \\
\hline Pension * age & & $\begin{array}{l}.181 \\
(.140)\end{array}$ & & $\begin{array}{l}-.073 \\
(.025)\end{array}$ \\
\hline $\mathrm{R}^{2}$ & .635 & .650 & .642 & .690 \\
\hline
\end{tabular}


Table 11. Evidence on the Impact of Pension Coverage, Pension Compensation, and Pension Capital Loss on Years of Service, Job Change Probability, and Quit Probability

Results

Sample and

dependent

variable

Pension
coverage
rvival rates are
-47 percentage
ints higher

May CPS 1979-1983;

survival rates across

100 pension/age/

industry/occupation

cells

May 1983 CPS; years

of service

1975-82 PSID household heads under 55; job change probability

1975-82 PSID household heads under 55; quit probability

1975-82 PSID household heads under 55; hazard for additional years of service on 1975 job

1971-81 NLS older men; job change probability

1971-81 NLS older men; quit probability
Years of service increases by 34 to $49 \%$

Reduces job change probabilities for all four age groups

Reduces quit probabilities for $25-34,35-44,45-54$ age groups

Additional years of service $28 \%$ higher

No effect

No effect

No effect
Reduces job change probability by 11 to 16 percentage points
Years of service increases by $5 \%$ with each dollar

No effect in any group

No effect in any group

No effect in any grap
Positively correlated with years of service

Reduces job change probabilities for 45-54 year olds; no effect on other age groups

Additional years of service 228 higher for $\$ 10,000$ loss

Source: Steven Allen, Robert Clark, and Arm McDermed, "Job Mobility, Older Workers and the Role of Pensions," Final Report for U.S. Department of Labor Contract No. J-9-M-5-0049, October 1986. 
BIBLIOGRAPHY

Allen, Everett, Joseph Melone, and Jerry Rosenbloom, Pension Planning, Homewood, Ill.: Richard Irwin, 1984.

Allen, Steven, "Compensation, Safety, and Absenteeism: Evidence from the Paper Industry, "Industrial and Labor Relations Review 34 (January 1981): 207-218.

Allen, Steven and Robert Clark, "Unions, Pension Wealth, and Age Compensation Profiles," Industrial and Labor Relations Review, 39 (July 1986): 502-17.

Allen, Steven, Robert Clark, and Ann McDermed, "Job Mobility, Older Workers and the Role of Pensions," Final Report for U.S. Department of Labor Contract No. J-9-M-5-0049, October 1986.

Allen, Steven, Robert Clark, and Daniel Sumner, "Postretirement Adjustments of Pension Benefits," Journal of Human Resrouces, XXI (Winter 1986): 118-27.

Andrews, Emily, The Changing Profile of Pensions in America, Washington, D.C.: Employee Benefit Research Institute, 1985.

Brown, Charles and James Medoff, "Trade Unions in the Production Process," Journal of Political Economy, 86 (June 1978): 355-78.

Bulow, Jeremy, "What Are Corporate Pension Liabilities?" Quarterly Journal of Economics, XCVII (1982): 435-52.

Bulow, Jeremy, Randal1 Morck, and Lawrence Summers, "How Does The Market Value Unfunded Pension Liabilities?" NBER Working Paper No. 1602, April 1985.

Clark, Robert, and Joseph Spengler, The Economics of Individual and Population Aging, New York: Cambridge University Press, 1980.

Clark, Robert, Steven Allen, and Daniel Sumner, "Inflation and Pension Benefits," in Richard Ippolito and Walter Kolodrubetz (Eds.) The Handbook of Pension Statistics 1985, Chicago: Commerce Clearing House, 1986.

Clark, Robert and Ann McDermed, "Earnings and Pension Compensation: The Effect of Eligibility," Quarterly Journal of Economics, XCXI (May 1986a): 341-61.

Clark, Robert and Ann McDermed, "Labor Contracts, Pension Plans, and Lifetime Earnings," North Carolina State University, unpublished paper (1986b).

Ehrenberg, Ronald, "Retirement System Characteristics and Compensating Wage Differentials in the Public Sector," Industrial and Labor Relations Review 33 (July 1980): 470-483. 
Feldstein, Martin and Randall Morck, "Pension Funding Decisions, Interest Rate Assumptions, and Share Prices," in Avi Bodie and John Shoven (Eds.), Financial Aspects of the United States Pension System, Chicago: University of Chicago Press (1983): 177-210.

Feldstein, Martin and S. Seligman, "Pension Funding, Share Prices and National Saving," Journal of Finance, 36 (1981): 801-24.

Fields, Gary, and Olivia Mitche11, Retirement. Pensions, and Social Security, Cambridge: MIT Press, 1984.

Freeman, Richard, "Union, Pensions, and Union Pension Funds," in David Wise (ed.), Pensions, Labor, and Individual Choice, Chicago: University of Chicago Press (1985): 89-122.

Greenough, William and Francis King, Pension Plans and Public Policy, New York: Columbia University Press, 1976.

Ippolito, Richard, "The Labor Contract and True Economic Pension Liabilities," American Economic Review, LXXV (December 1985a): 1031-43.

Ippolito, Richard, "The Economics of Pensions and Mobility," unpublished paper (1985b).

Ippolito, Richard, "The Economic Function of Underfunded Pension Plans," Journal of Law and Economics, 28 (1985c): 611-51.

Ippolito, Richard, Pensions, Economics and Public Policy, Homewood, I11.: Dow Jones-Irwin, 1986.(a)

Ippolito, Richard, "A Study of the Regulatory Impact of ERISA," unpublished paper 1986.(b)

Ippolito, Richard, "Why Federal Workers Don't Quit," Journal of Human Resources, 1987 forthcoming.

King, Francis, "Indexing Retirement Benefits," The Gerontologist, 22 (December 1982): 488-92.

Kotlikoff, Laurence and David Wise, "Labor Compensation and the Structure of Private Pension Plans," in David Wise (Ed.) Pensions, Labor, and Individual Choice, Chicago: University of Chicago Press, (1985): 55-85.

Kreps, Juanita, "Age, Work and Income," Southern Economic Journal, 44 (1977): 1423-37.

Lazear, Edward, "Why Is There Mandatory Retirement?" Journal of Political Economy, 87 (December 1979): 1261-1284.

Lazear, Edward, "Agency, Earnings Profiles, Productivity and Hours

Restrictions," American Economic Review, 71 (September 1981): 606-20. 
Lazear, Edward, "Pensions As Severance Pay," in Zvi Bodie and James Shoven (Eds.), Financial Aspects of the United States Pension System, Chicago: University of Chicago Press, (1983): 57-90.

Lazear, Edward, "Incentive Effects of Pensions," in David Wise (ed.), Pensions, Labor, and Individual Choice, Chicago: University of Chicago Press (1985): 253-282.

Malcomson, James, "Work Incentives, Hierarchy, and Internal Labor Markets," Journal of Political Economy 92(1984): 486-507.

McCormick, Barry and Gordon Hughes, "The Influence of Pensions on Job Mobility," Journal of Public Economics, 23 (1979): 939-56.

Mitche11, Olivia, "Fringe Benefits and Labor Mobility," Journal of Human Resources, XVII (1982): 286-98.

Mitche11, Olivia, "Fringe Benefits and the Cost of Changing Jobs," Industrial and Labor Relations Review, 36 (October 1983): 70-78.

Mitchell, Olivia, and Emily Andrews, "Scale Economies in Private Multiemployer Pension Systems," Industrial and Labor Relations Review 34 (1981): $522-530$.

Mitchell, Olivia, and Gary Fields, "The Effect of Pensions and Earnings on Retirement: A Review Essay," in Ronald Ehrenberg (ed.), Research in Labor Economics, Vo1. 5, Greenwich, Conn.: JAI Press (1982): 115-155.

Mitchel1, Olivia, and Silvana Pozzebon, "Wages, Pensions and the Wage-Pension Tradeoff," unpublished paper, 1986.

Munnell Alicia, Pensions for Public Employees, Washington, D.C.: National Planning Association, 1979.

President's Commission on Pension Policy, An Interim Report, Washington, D.C.: November 1980.

Rees, Albert, The Economics of Trade Unions, Chicago: University of Chicago Press, 1962 .

Riley, Matilda, and Ann Foner, Aging and Society, Vo1. I, New York: Russell Sage Foundation, 1968.

Rosen, Sherwin, "Hedonic Prices and Implicit Markets," Journal of Political Economy, 82(1984): 34-55.

Schiller, Bradley, and Randall Weiss, "The Impact of Private Pensions on Firm Attachment," Review of Economics and Statistics 61 (August 1979): 369-380.

, "Pensions and Wages: A Test for Equalizing Differences," Review of Economics and Statistics 62 (November 1980): 529-538. 
Schulz, James, The Economics of Aging, Belmont, Cal.: Wadsworth Publishing Company, 1985.

Smeeding, Timothy, "The Size Distribution of Wage and Nonwage Compensation: Employer Cost versus Employee Value," in Jack Triplett (Ed.), The Measurement of Labor Costs, Chicago: University of Chicago Press, 1983.

Smith, Robert, "Compensating Differentials for Pensions and Underfunding in The Public Sector, "Review of Economics and Statistics 63 (August 1981): 463-468.

Smith, Robert, and Ronald Ehrenberg, "Estimating Wage-Fringe Trade-Offs: Some Data Problems," in Jack E. Triplett (ed.), The Measurement of Labor Cost, Chicago: University of Chicago Press (1983): 347-369.

Urban Institute, "Financial Retirement Incentives in Private Pension Plans," Report submitted to the U.S. Department of Labor, Washington, D.C.: 1982 .

U.S. Department of Labor, Findings From the Survey of Private Pension Benefits Amounts, Washington: U.S.G.P.O., 1985.

Viscusi, W. Kip, "Self-Selection, Learning-Induced Quits, and the Optimal Wage Structure," International Economic Review 21 (1980): $529-546$.

, "Nontransferable Pensions as a Mobility-Reduction Device," in David Wise (ed.), Pensions, Labor, and Individual Choice, Chicago: University of Chicago Press (1985): 223-248. 
</ref_section> 